\title{
Micromorphological investigations on two paleosol horizons of the loess/paleosol sequence of Madaras, Hungary
}

\author{
Dávid Gergely Páll \\ Defence Association of Hungarian Geology, Szeged \\ Sándor Gulyás \\ Department of Geology and Paleontology \\ University of Szeged, Szeged \\ Pál Sümegi \\ Department of Geology and Paleontology \\ University of Szeged, Szeged
}

Júlia Hupuczi

Faculty of Agriculture,

University of Szeged, Szeged

Zsolt Veres

Defence Association of Hungarian Geology, Szeged

\begin{abstract}
The loess/paleosol sequence near the village of Madaras is an outstanding record of Late Quaternary paleoenvironmental and paleoclimatic changes in Hungary and the entire Carpathian Basin. The present study highlights the results of preliminary micromorphological investigations implemented on 24 samples taken from two pre-selected pedogenized horizons of the sequence. Our work yielded interesting results regarding the evolutionary history and modes of pedogenesis in the studied section.
\end{abstract}

Key words: micromorphology, malacology, loess, paleoenvironmental

\section{Introduction/study area}

The outcrop of Madaras exposing loess/paleosol (L/P) sequences of the Late Quaternary is found at the northernmost fringe of the Bácska Loess Plateau in the northern parts of the Telecska Hills in the area of the Danube-Tisza Interfluve (Nebojszki 2005) (Fig. 1). These sequences record paleoenvironmental and paleoclimatic changes that occurred in the area during the past ca. 20 kys. During the Quaternary the area experienced continuous movement along the Paks, Southern Jászság and Csongrád-Szeged Depressions yielding a highly transformed morphology (Rónai 1977). In the case of Madaras the L/P complex overlies older eolian sequences (Marosi and Somogyi 1990). Loess deposits covering alluvial fans have been extensively studied from several aspects

Addresses: D. G. Páll, Zs. Veres: H-6723 Szeged, Jósika utca 35, Hungary J. Hupuczi: H-6800 Hódmezővásárhely, Andrássy út 15, Hungary S. Gulyás, P. Sümegi: H-66721 Szeged, Egyetem utca 2-6, Hungary Corresponding author e-mail: pall.david.gergely@gmail.com

Received: June 29, 2012; accepted: October 15, 2013 


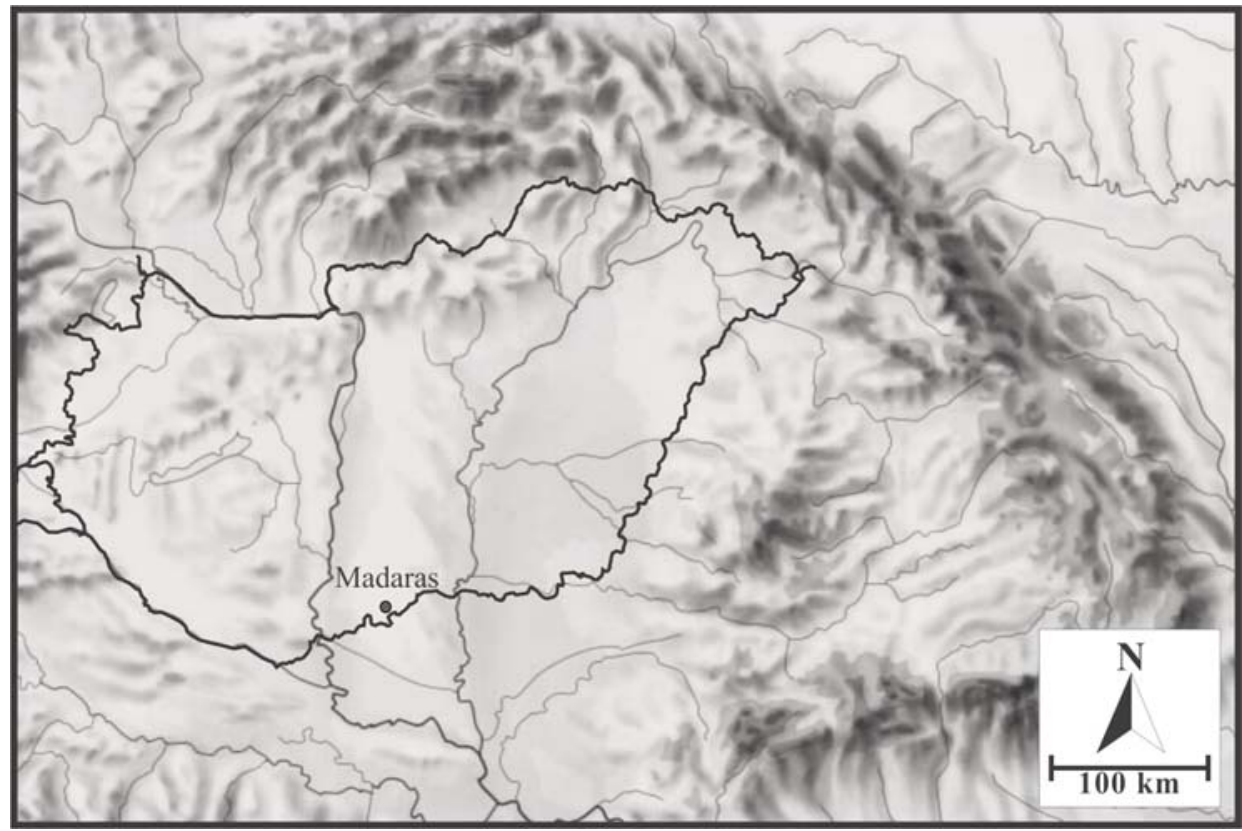

Fig. 1

Location of the study site

including archeology (T. Dobosi 1967; T. Dobosi and Kôhegyi 1989), anthracology (Stieber 1967), malacology (Krolopp 1989; Hupuczi and Sümegi 2010), and sedimentology (Molnár and Krolopp 1978). The present-day outcrop exposes a wall of ca. $10 \mathrm{~m}$ of the L/P sequence as a result of human activities (Molnár and Krolopp 1978). Due to the elevated position of the site, sediment accumulation must have been continuous during the past in the area (Jakab et al. 2004). Our work was focused on the analysis of the micromorphological features of a pedogenized unit found in the central part of the section and dated to the terminal Weichselian (Weichselian 3) (Sümegi and Krolopp 1995), as well as a chernozem-like paleosol horizon (Molnár and Krolopp 1978) developed on sands at the bottom of the section dated to the Weichselian 2-3 (Sümegi and Krolopp 1995).

\section{Material and methods}

Measurements of carbonate and organic content

Carbonate (CC) and organic content (OC) of the samples was determined via Dean-type loss-on-ignition (Dean 1974). 
Field sampling for micromorphological investigations

There are several methods available from the literature, which discuss sampling techniques from unconsolidated sediments and palesols as well as archeological objects yielding undisturbed samples for study (Sümegi 2003a). All methods differ to some degree depending on the peculiarities of the deposits under study and the problems to be addressed. All of them, however, aim to minimize on-site sample disturbance (FitzPatrick 1993). The chosen horizons of the referred loess section were sampled by retrieving 6 larger blocks of 20x10x10 cm dimension. Orientations of the blocks were noted and photographed in the field (FitzPatrick 1993). The blocks were then individually wrapped and transported to the lab for further subsampling for thin sections.

\section{Sampling for thin-section analysis}

The 6 sampled blocks were impregnated in the lab with epoxy resin (ARALDITE AZ 103) and subsequently subsampled for oriented thin-section analysis, yielding 24 thin sections. Sub-sampling targeted the terrestrial loess as well as the underlying pedogenized horizon and the transition between the two in the case of the block derived from the central part of the L/P profile (Hupuczi and Sümegi 2010). A similar approach was adopted for the block taken from the bottom of the section (Molnár and Krolopp 1978) (Fig. 2). For the description the international (Bullock et al. 1985) and Hungarian protocols for soil description in thin section (Szendrei 2000) were adopted. Visual description under the microscope was complemented by computer-aided image analysis to enhance identification (Dezső 2011).

For the preparation of the thin sections the methods proposed by Szendrei (2000) and Dezső (2011) were systematically followed. The block samples were dried in a drying oven at a temperature of $30^{\circ} \mathrm{C}$ for a week. Then the dried blocks were sliced for subsamples. The obtained subsamples were impregnated for 1 week and allowed to dry for another week. Then the subsamples were finalized via impregnation in epoxy resin (ARALDITE AZ 103) and were machine sliced (BUEHLER PETROTHIN). The initial blocks were vertically subsampled allowing us to cover a depth of ca. $60 \mathrm{~cm}$ with 12 thin-section samples. The final outcome was 15-30 microns thick after hours of machine slicing and polishing (Szendrei 2000; Dezsô 2011). Following the classical description a quantitative as well as morphological analysis of each thin section was implemented under a polarization microscope type NIKON Eclipse E600 (Bullock et al. 1985; FitzPatrick 1993; Szendrei 2000). The parts of interest were photo-archived (CANON EOS 30D). The obtained photos were further analyzed using image analysis software (Corel Photo Paint X5, ImageJ and Zoner Panorama Maker). Computer-aided image analysis was implemented on 24 selected thin-sections. 


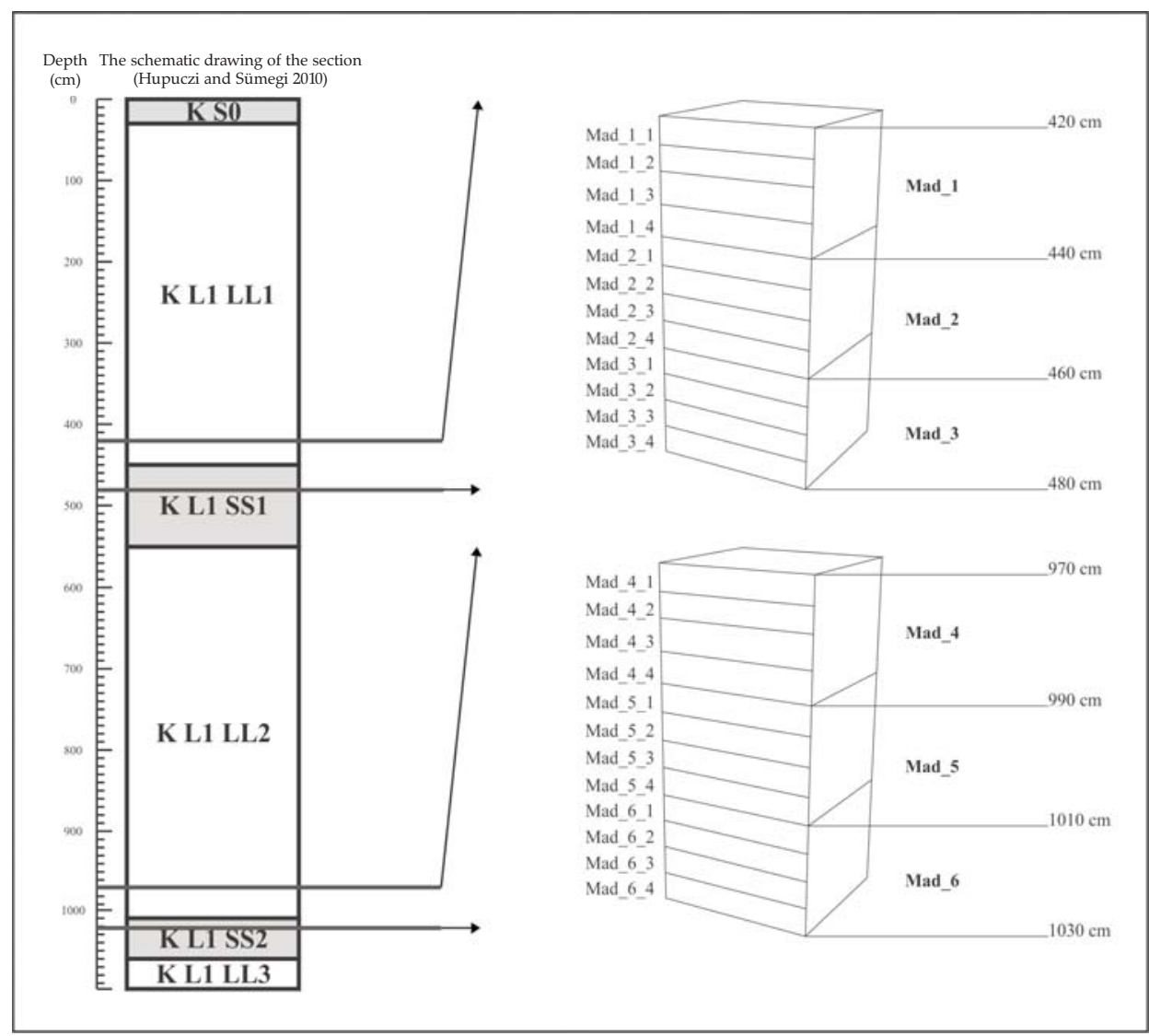

Fig. 2

Simplified sketch of the studied L/P section (modified after 8) with the location of the block samples and the subsamples of the thin sections

\section{Results}

Carbonate and organic content from the two pre-selected horizons of the section

Horizon $1(420-480 \mathrm{~cm})$

The organic content ranges between the values of 0 and $6 \%$ in the $10-\mathrm{m}$ section, with the highest values recorded in the uppermost A horizon of the modern soil. There is a gradual downward decrease to an average of $1 \%$ generally characteristic of the loessy zones. This value is double in the paleosol horizon found in the central part of the section between the depths of 4 and $5 \mathrm{~m}$, which is the focus of our work (2-3\%) (Fig. 3). The carbonate content ranged between 4 and $16 \%$ in the entire section. The lowermost values were recorded in the 


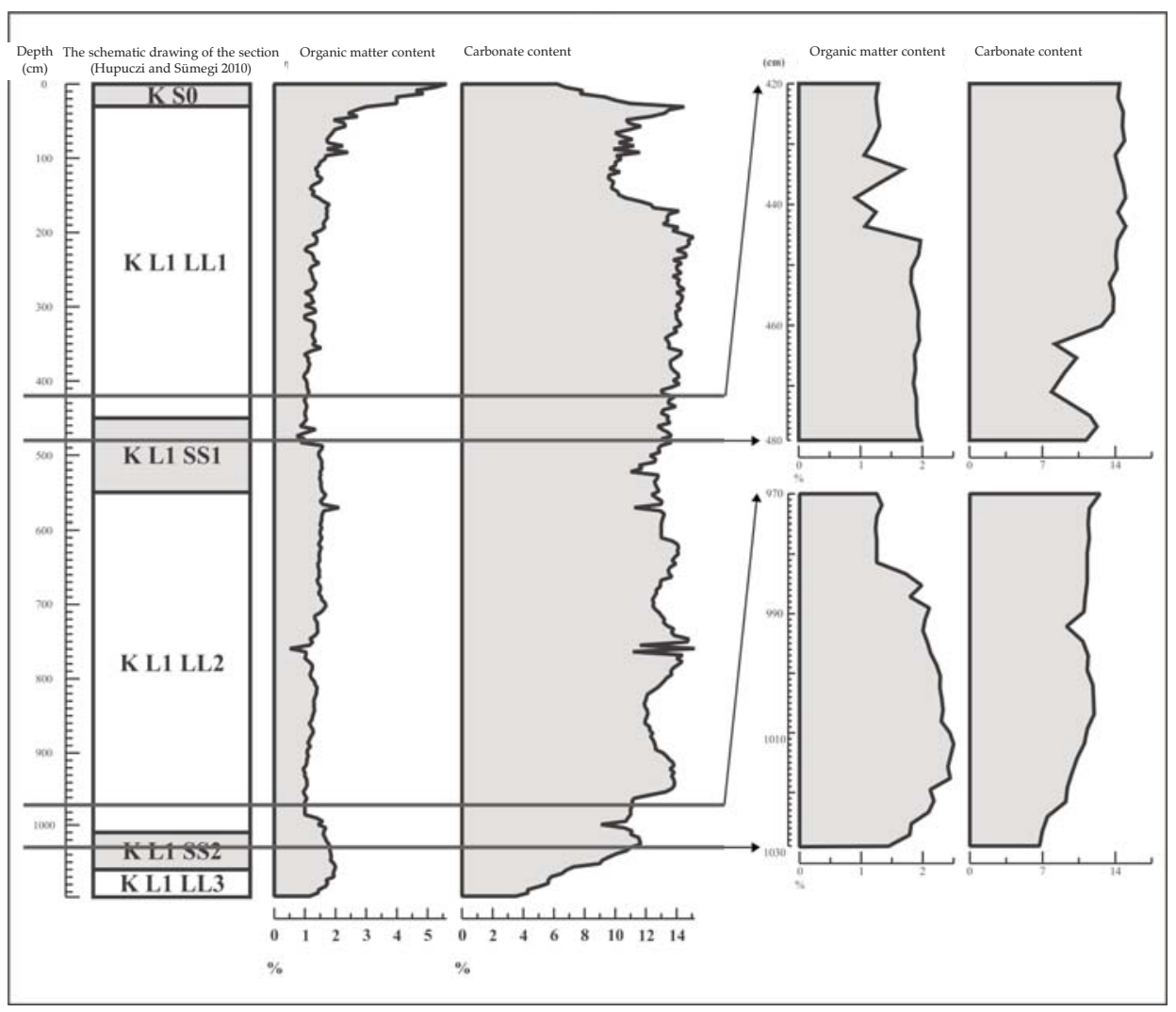

Fig. 3

Organic (OC) and carbonate content (CC) of samples along the studied section

uppermost part of the section corresponding to the modern soil horizon (4-8\%). The remaining parts had values ranging between 12 and $14 \%$. In the studied soil horizon this parameter is generally low, ranging between 5 and $6 \%$.

\section{Horizon 2 (970-1040)}

There is a general increase in the organic content of the samples in this part of the studied section as well (Molnár and Krolopp 1978) (2-3\%). Values are roughly double those of the overlying loessy deposits (Fig. 3). The carbonate content is around the average (12-14\%) up the upper part of the referred horizon (960-970 $\mathrm{cm})$. There is a drastic drop downward from here to values of ca. $4-6 \%$. 


\section{Thin section description}

Detailed micromorphological description of the subsamples

Madaras_1 (420-440 cm; Mad_1_1-4) (Fig. 4)

This sample derives from the loessy deposits directly overlying the upper paleosol (Hupuczi and Sümegi 2010). Organic and inorganic skeletal elements are equally present in the thin section. The matrix is generally homogeneous, displaying no orientation at all and/or slightly oriented around the pores. In some places the matrix is slightly concentrated. The pore margins are fringed by accumulated limonitic matrix. Pore filling is highly variable, ranging from semi to fully filled pores. Larger grains are generally absent. Some rectangular elements are discernible in the matrix including rectangular pores and macropores. Bioturbation marks are subordinate along the studied horizon. The texture of the matrix is porphyric or lacking any structural orientation.

\section{Madaras_2 (440-460 cm; Mad_2_1-4) (Fig. 5)}

This sample represents a transition between the loess and the paleosol (Hupuczi and Sümegi 2010). The matrix contains a wide range of organic (plant remains) and inorganic (gastropod shell) skeletal parts. The matrix is generally homogeneous, displaying orientation only along the pores. There is a marked increase in iron precipitates, both in the form of nodules and accessory precipitates in the matrix. Along the iron nodules an accumulation of ferruginous matrix is also discernible. There is a marked increase in the number of bioturbation traces; the number of filled cavities related to them is likewise generally higher. The texture of the matrix is porphyric or sometimes compacted, which tends to have show slight lamination in the lower part of the studied horizon (FitzPatrick 1993).

\section{Madaras_3 (460-480 cm; Mad_3_1-4) (Fig. 6)}

This sample corresponds to the upper paleosol of the section (Hupuczi and Sumegi 2010). Organic (plant remains, biomorphs) and inorganic skeletal remains are equally present in the studied thin sections. The matrix is generally homogeneous, displaying slight orientation around the cavities and macropores. Even laminar parting was discernible. Orientation of the matrix is equally visible around the skeletal parts. The texture is porphyric with a common occurrence of iron and manganese accumulations and separations. There is a clear accumulation of the ferruginous matrix around iron nodules with sharp boundaries. Bioturbation marks are common, many of them having larger mineral grains inside. The structure of the ferruginous matrix is sometimes ringlike, but a horizontal distribution is much more common. The number of rectangular aggregates is likewise higher. Illuviation traces are often recorded in and around the cavities having a different color from that of the matrix. 

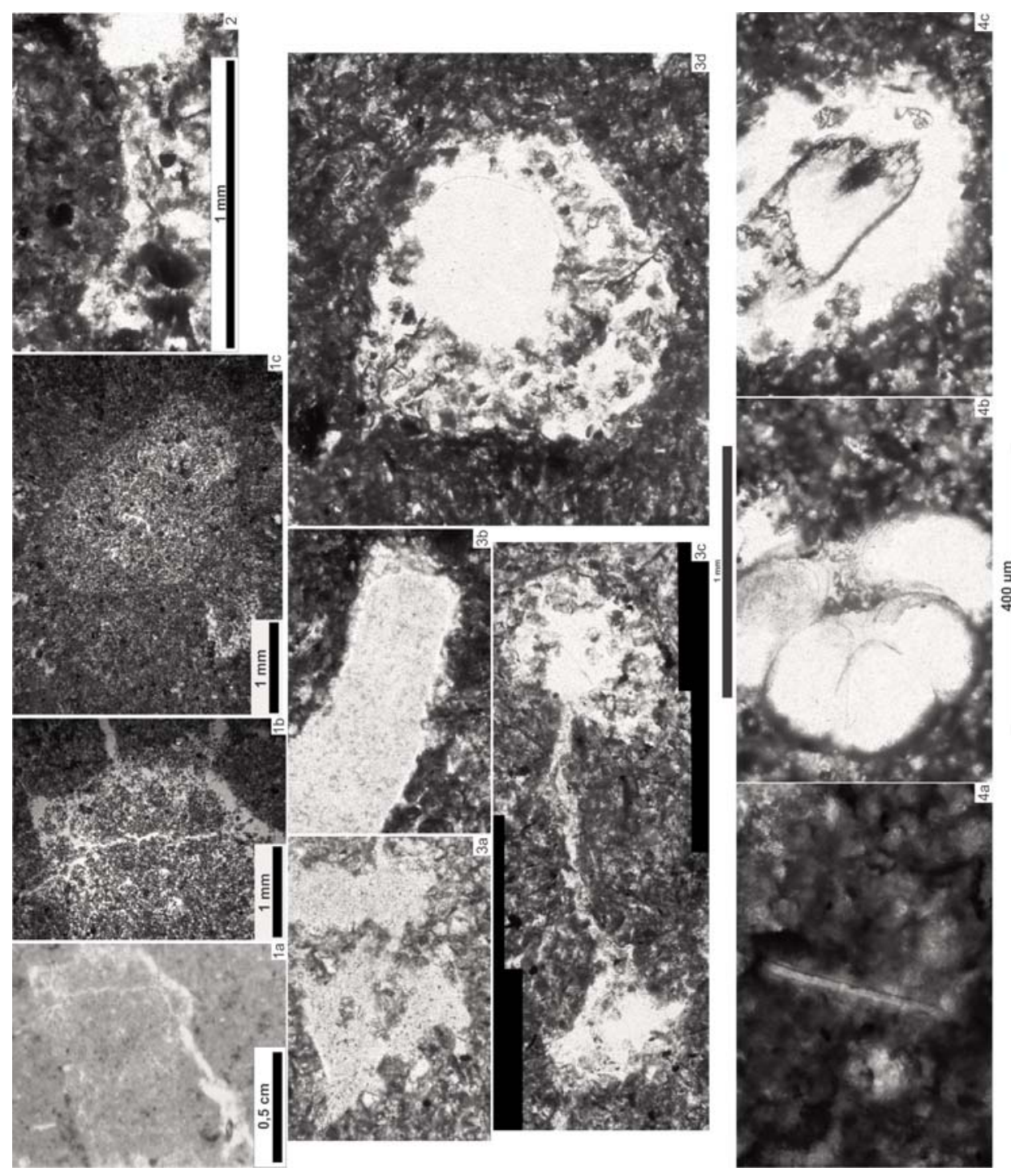

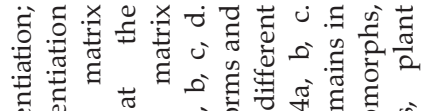

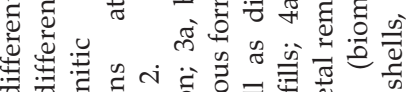

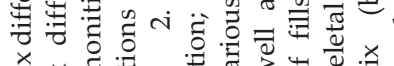

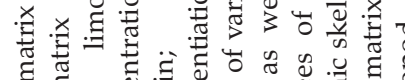
呵

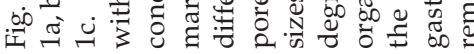




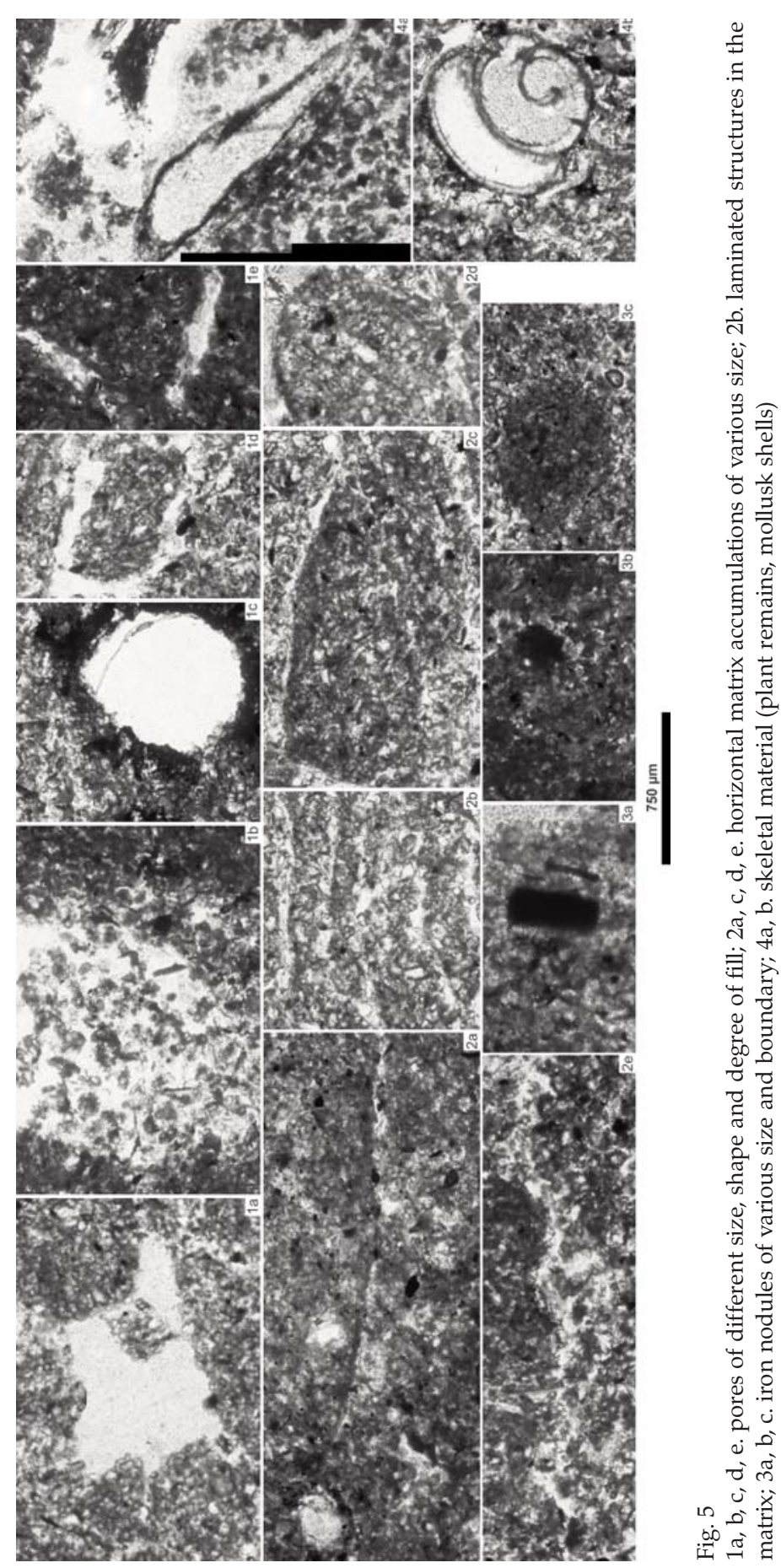

Central European Geology 56, 2013 


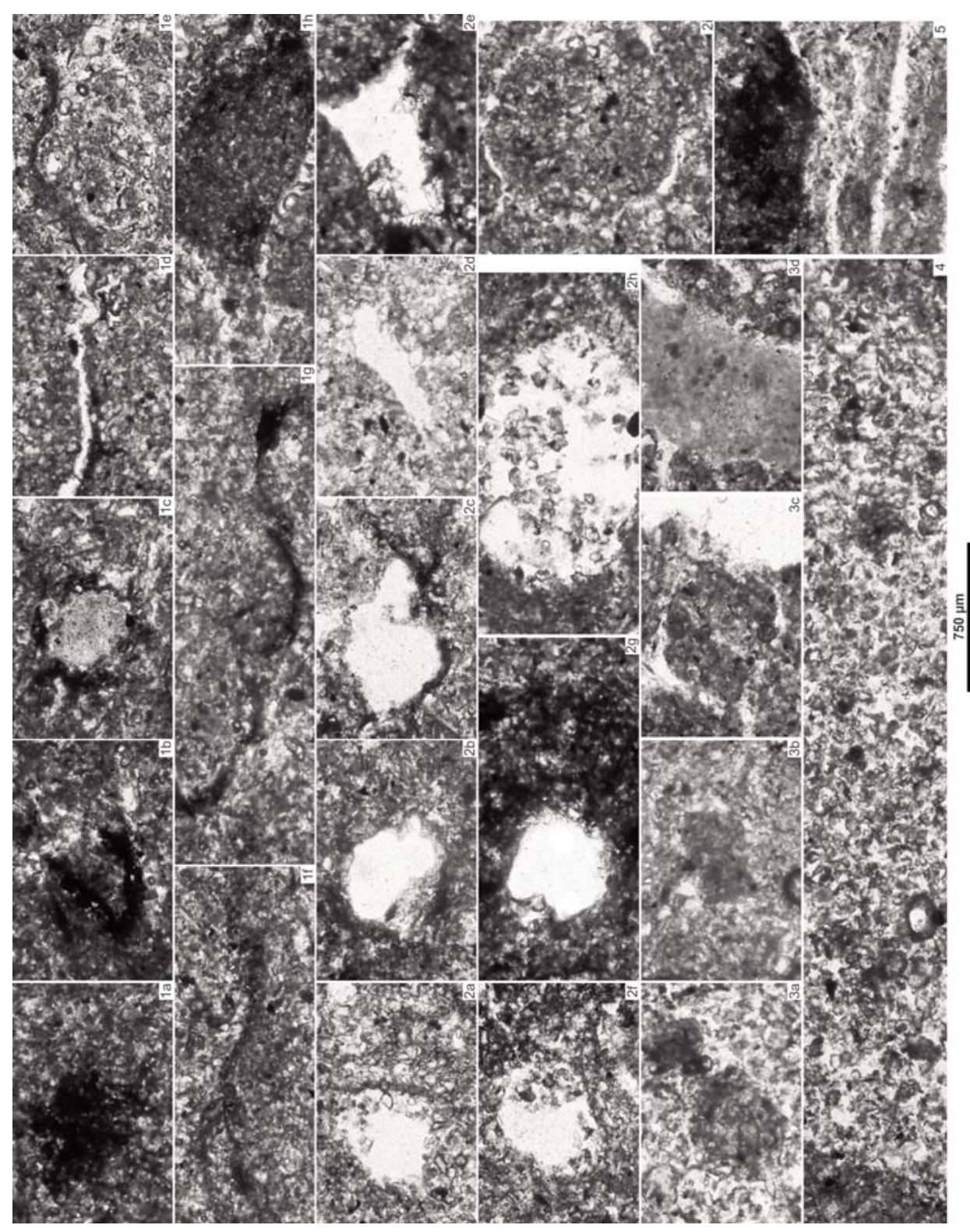

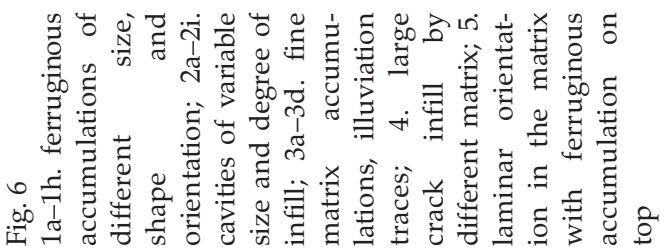


Madaras_4 (970-990 cm; Mad_4_1-4) (Fig. 7)

This sample corresponds to the loessy horizon directly overlying the lower paleosol of the studied section (Molnár and Krolopp 1978). Organic (plant remains, biomorphs) and inorganic skeletal remains are equally present in the studied thin sections. The matrix displays no visible orientation apart from the areas around the skeletal remains, pores, and cavities. The texture is porphyric. Larger cavities and macropores are likewise present with an accumulation of ferruginous materials around the margins. Illuviation traces are absent. The number of bioturbation marks is negligible. Mineral grains of larger size often turn up in the matrix with a dominantly rectangular, sometimes oval shape and a random distribution. Ferruginous accumulations and separations are present but not common.

Madaras_5 (990-1010 cm; Mad_5_1-4) (Fig. 8)

This part corresponds to a transitional horizon between the loess and the underlying lower paleosol (Molnár and Krolopp 1978). Organic (plant remains, charcoal, biomorphs) and inorganic skeletal material (mineral grains) are equally present. The matrix displays no visible orientation apart from the areas around the skeletal remains, pores, and cavities. Larger iron precipitates with sharp and faint boundaries are surrounded by ferruginous accumulations of the matrix. Such accumulations are especially common at the bottom of the studied horizon. Unevenly scattered larger mineral grains of oval shape are also attested. In addition illuviation traces are also much more common in this part of the section. The amount of bioturbation is negligible. Some pine charcoal remains were also noted (K. Náfrádi, pers. communication).

Madaras_6 (1010-1030 cm; Mad_6_1-4) (Fig. 9)

This part corresponds to the paleosol layer at the bottom of the studied section (Molnár and Krolopp 1978). Organic (plant remains, charcoal, biomorphs) and inorganic skeletal material (mineral grains) are equally present in a size larger than average. The matrix is homogeneous without any orientation, apart from the rim of skeletal remains, pores, and cavities. Iron precipitates, nodules and accumulations are very common along this horizon with sizes larger than average. The number of bioturbation traces also increases. The pores are either empty or infilled. The quantity of mineral grains is high. Most of them have an oval or roundish shape and are randomly scattered in the matrix. Larger charcoal remains displaying signs of corrosion and erosion are also common. Illuviation traces are the highest in number in this part of the studied horizon. 

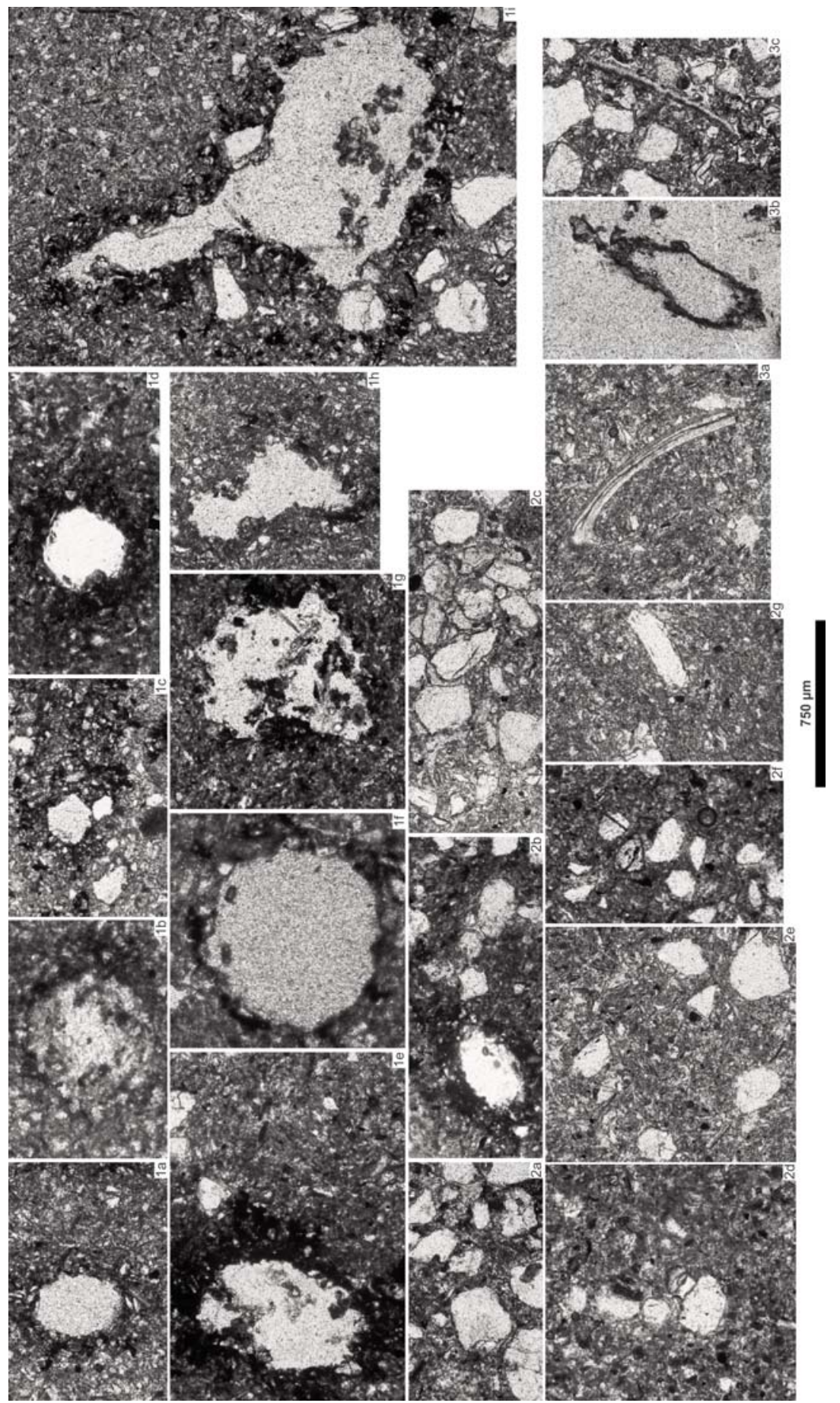

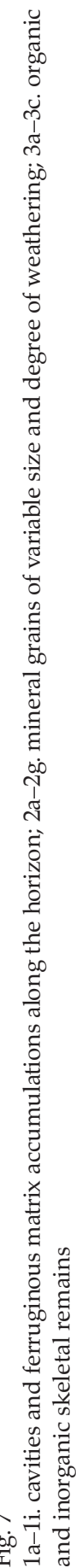

Central European Geology 56, 2013 


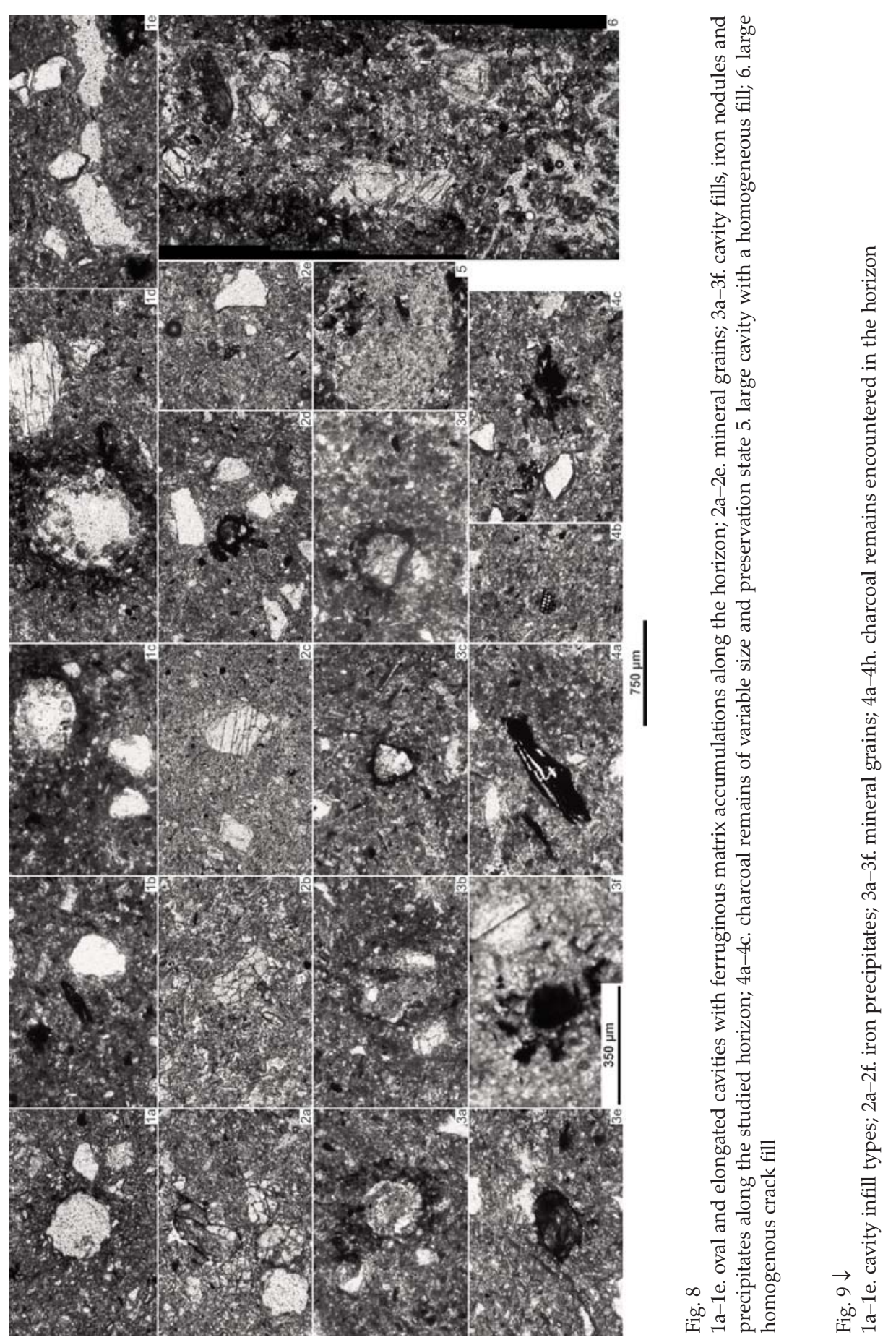

Central European Geology 56, 2013 


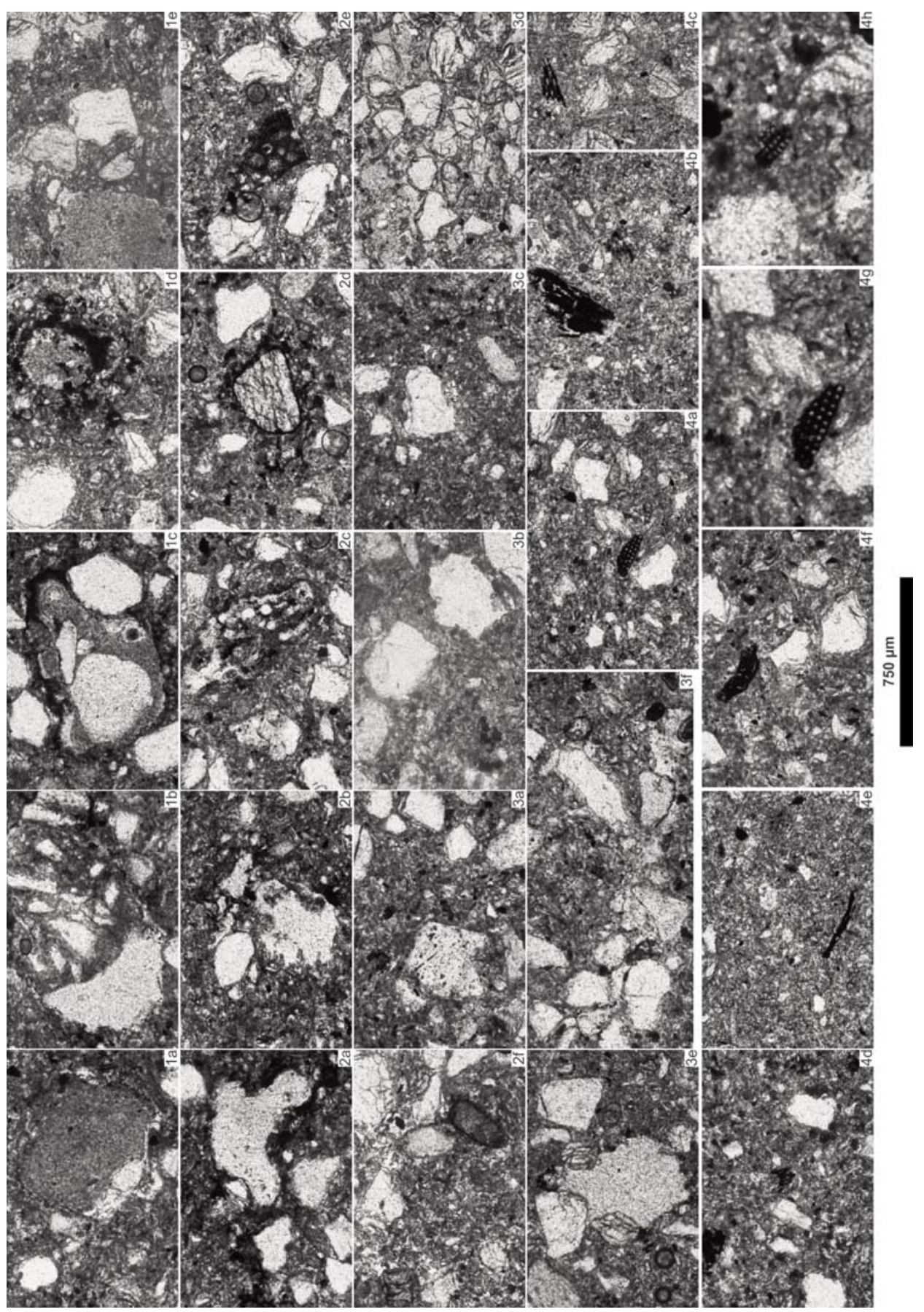

Central European Geology 56, 2013 
Results of pore size and shape parameterization studies

Results of pore parametric analysis of loose sediment from the middle part of the section

The average pixel value of pore and cavity areas ranges around a few hundred (Fig. 10) and is relatively stable, apart from a few exceptions (Mad_1_3 shell). An increase in the average values must be attributed to either the presence of outliers (like gastropod shells) or the presence of larger cracks in the thin sections. In the zone directly above the paleosol horizon there is a sharp increase in the number of pores and cavities as well as in bioturbation marks. The size of the pores is around a couple of hundred pixels, but in total they provide only a small percentage of the entire studied area of thin sections, implying a more compact nature of the sediment. The percentage of encountered pores ranges around $1-2 \%$ in the paleosol as well as in the transitional zone. These higher values must be attributed to bioturbation. The shape of encountered cavities and pores ranges from elongated, strongly elongated, weakly isometric, isometric to round (Skvortsava 1998; Szendrei 2000). The number of isometric pores and cavities is much higher than that of the elongate forms. Interestingly the elongated cavities are prevalent in the loessy and transitional horizons of the section. On the other hand oval and roundish pores and cavities predominate in the paleosol horizons. There is an outlier in the parameter for rounded pores within the loessy zone, where the plane of the thin section cut through the apex of a loess gastropod shell (Sümegi, pers. comm). The values for the shape factor in the studied horizons range between 0.4 and 0.7 (Skvortsava 1998; Szendrei 2000), indicating the presence of subangular, compact, cracked structures. This factor is above the value of 0.6 in the loessy horizon, implying the dominance of compact structures with fissures. In the transitional horizons characterized by a higher number of bioturbation marks (indicating greater disturbance), the shape factor values are between 0.5 and 0.6 , indicating a subangular, disturbed structure of the deposit. The shape factor was between 0.4 and 0.7 in the paleosol horizons, indicating a slightly disturbed, subangular, sometimes compact structure in the morphologies.

Results of pore parametric analysis of loose sediment from the lower part of the section

The number of identified pores along the referred horizon was highly variable, between 50 and 500 (Fig. 11). This must be attributed to several factors. The higher values at the top must be attributed to the presence of a secondary fissure. Similarly high values at the bottom, however, may indicate the shape of a larger piece of residual organic matter. The cavity field values along the section are

Fig. $10 \rightarrow$

Results of pore parametric analysis of loose sediment from the middle part of the section 


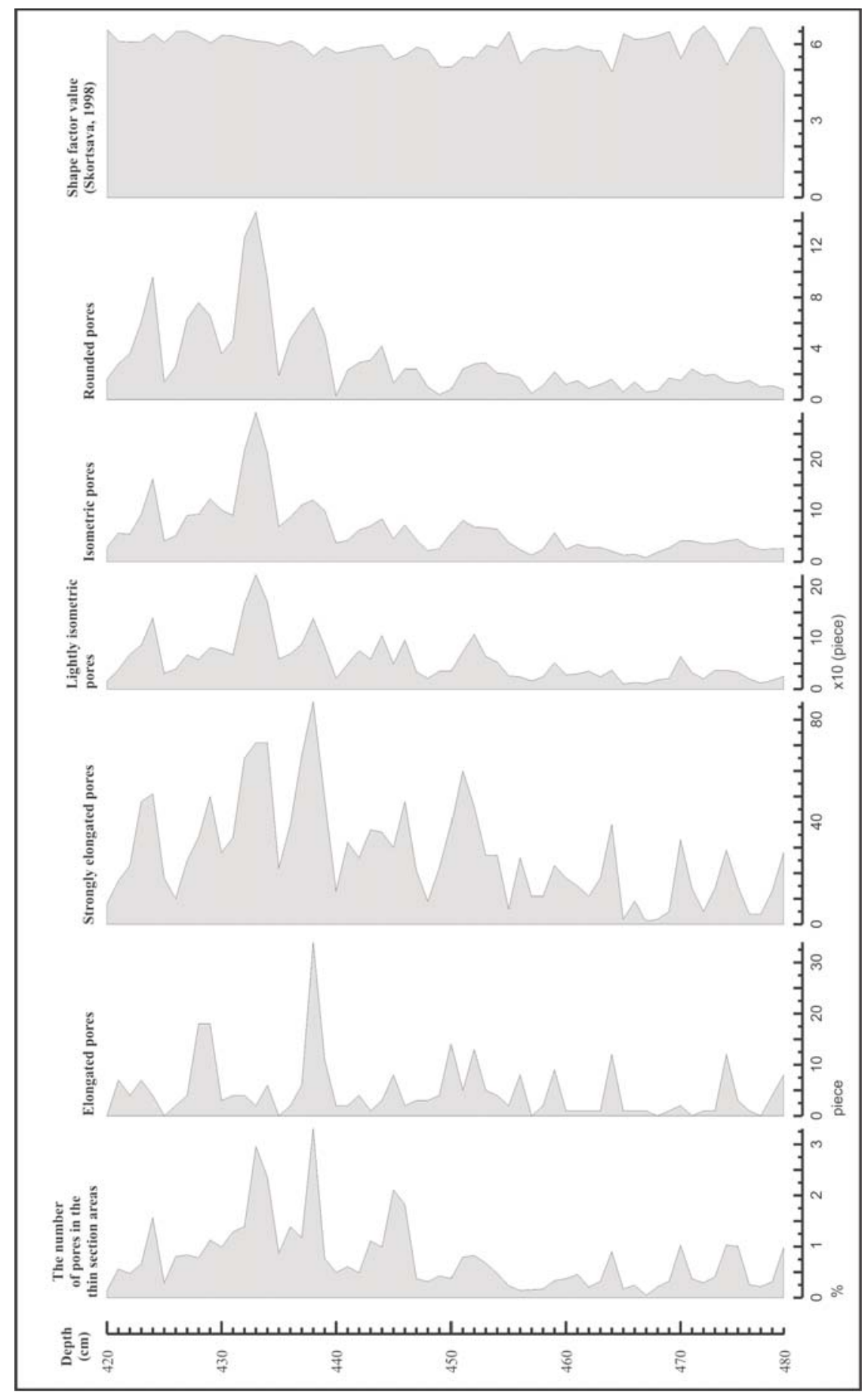

Central European Geology 56, 2013 
352 D. G. Páll et al.

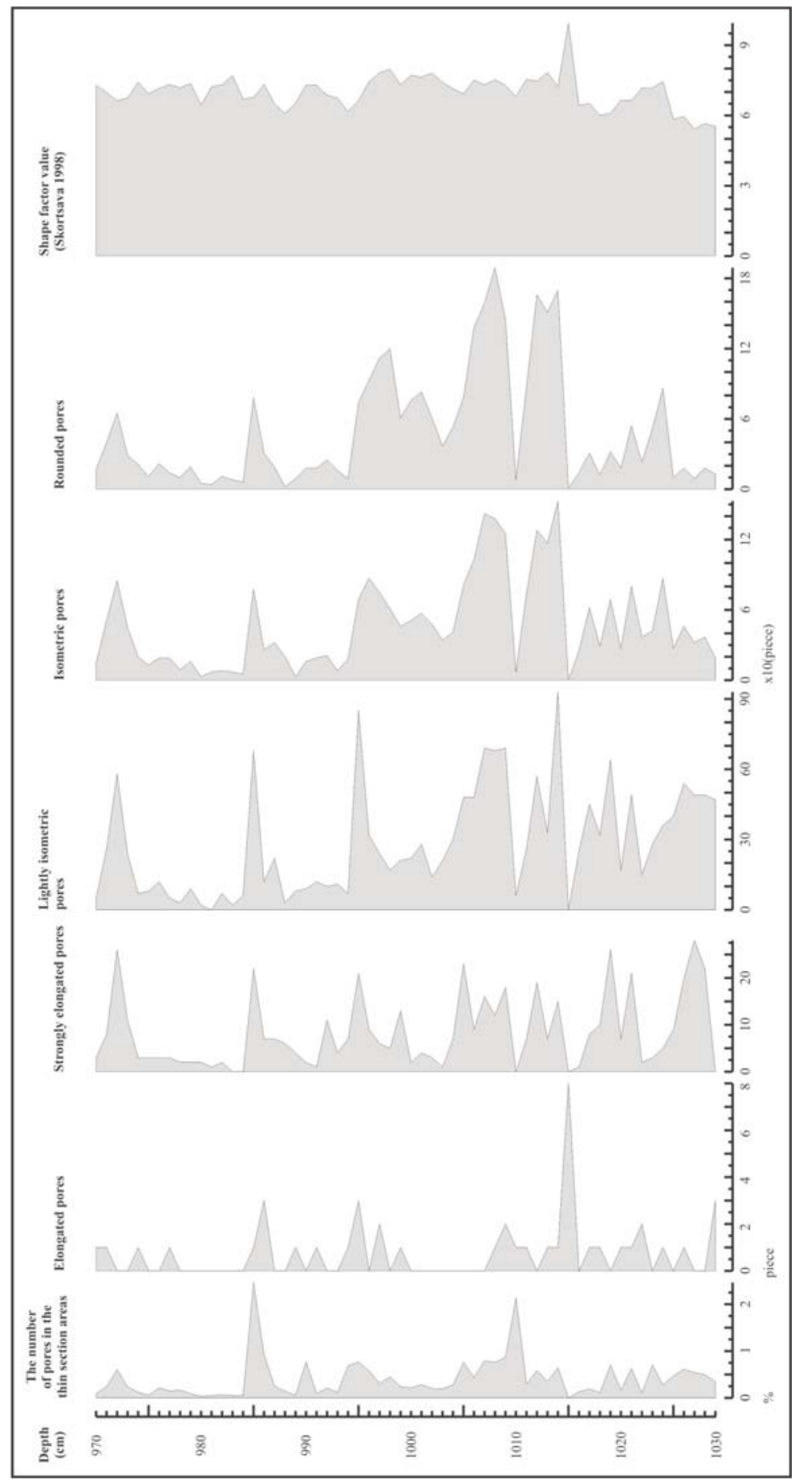

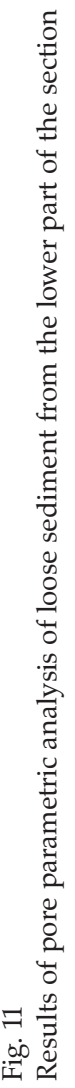

Central European Geology 56, 2013 
relatively similar, but in two cases take up an extreme value. The total area of ground glass along the section has values ranging between 0 to $3 \%$. Higher values can be found in the transitional horizon, while the lower values are found in the loess horizon. The number of elongated cavities is small; only the transition and the soil-like horizons are notable for their higher numbers. The largest number of the elongated pores ("cracks") are in the soil-like horizon and must be related to some turbation activity. The number of highly elongate pores is larger than that of elongate pores. However, the trends in both values are similar displaying an increase in the transitional and paleosol horizons. The oval and circular macropores and cavities are present in the largest number in these horizons as well. Shape factor values range between 0.4 and 1 in this part of the section. These values are between 0.6 and 0.8 in the loessy zones as well as in the transitional horizons, indicating a compact microstructure with negligible or no bioturbation activity. In the upper part of the paleosol horizon the values indicate unstructured morphologies. In the fully developed paleosol, shape factor values range between 0.6 and 0.8 , with a gradual decrease to 0.4 and 0.6 , indicating the appearance of subangular, blocky structures.

\section{Discussion}

According to the results of geochemical (organic content (OC), carbonate content (CC)) and micromorphological investigations carried out on selected sections of the Madaras loess profile (Jakab et al. 2004) minor fluctuations in sediment accumulation most likely representing paleoenvironmental perturbations, could be attested in a seemingly macroscopically-homogeneous section, where loessy horizons are hard to distinguish from those having been subjected to pedogenesis of various degree in the field. The loessy zones are generally characterized by more compact microstructures with a matrix lacking any particular orientation. Minor structuring of the matrix is present along the pores alone; the number of these is, however, much lower compared to the transitional and paleosol zones or horizons. Bioturbation marks are also rare in the loessy zones and relatively more abundant in the transitional and fully developed paleosol zones. Likewise the number of iron and manganese precipitates and nodules, as well as ferruginous accumulations in the matrix, is reduced in the loessy zones compared to the transitional and paleosol horizons. The loessy zones are furthermore characterized by lower OC values and lower concentration of organic skeletal remains. CC values are around the average characterizing the rest of the loessy horizons of the entire section. The cavities are also reduced in the loessy horizon compared to the transitional and paleosol horizons. The loessy horizon is predominated by elongate pores and cavities, reflecting the influence of post-depositional secondary processes. In the transitional horizons there is a general increase in the OC as well as the number of organic remains observed in the thin sections compared to the loessy horizons. 
This is accompanied by a gradual decrease in the CC values. Charred wood remains also turn up in the thin sections. The matrix is predominantly unstructured, displaying some orientation along the pores and cavities. The number of these is higher than in the previous loessy zone. Horizontal "threadlike" iron separations, some of which are connected to pores and cavities, also turn up. Iron nodules with a sharp or fading boundary also occur in larger quantities here. Rectangular accumulation structures in the matrix are also discernible, most likely reflecting the influences of wetting and drying (Szendrei 2000). Ferruginous accumulations in the matrix are also characteristic of this horizon. According to the received shape factor values, the transitional horizons are not as compact and unstructured as the loessy horizons (Skvortsava 1998; Szendrei 2000), but represent some sort of transition to blocky microstructures. The number of filled pores and cavities, with a dominance of mineral grain fills, also increases here. The distribution and shape of these mineral grains is rather random. The general shape of the indicated mineral grains indicates less intense weathering than in the typical paleosol horizons.

There is a general increase in the OC values of the typical paleosol horizons (Molnár and Krolopp 1978; Hupuczi and Sümegi 2010), parallel to that of the organic skeletal remains (charcoal). The matrix tends to be oriented along the pores and cavities in the company of ferruginous accumulations. Iron nodules and precipitates are commonly surrounded by a matrix of ferruginous material accumulations displaying a halo-like structure. The number and size of illuviation traces is also higher compared to the other studied zones. Laminar structures in the matrix also occur here, with thick ferruginous material accumulations on the top. The shape of pores and cavities is predominantly circular; elongate forms are present only subordinately. Bioturbation marks are fairly common, most of which are infilled by large mineral grains. The CC content in the zone suffering pedogenesis is significantly reduced. Shape factor values indicate the dominance of blocky structures (Skvortsava 1998; Szendrei 2000). The development of such structures is partly attributable to heightened bioturbation activities, and/or alternating wetting and drying or freezing/thawing of the deposit (Szendrei 2000). Accumulations of larger mineral grains are also common, displaying a random distribution in the thin sections with accumulations in the inner margins or pores, cracks and cavities. Ferruginous accumulations in the matrix between the referred mineral grains are also common.

\section{Conclusion}

Loess-covered regions hosted numerous open pits and brickyards supporting construction material production over the past centuries in Hungary, including our study site of the brickyard of Madaras located at the northern edge of the Backa Loess Plateau. The section of the brickyard exposes a loess/paleosol sequence for the past ca. 30 kys. Paleoenvironmental parameters continuously 
changed from the beginning of the Weichselian 2-3 (Sümegi and Krolopp 1995) representing the initiation of loess accumulation at this location in the Carpathian Basin. Thus in many cases not only loess deposits were formed (Hupuczi and Sümegi 2010). The lowest part of the section hosts a chernozem-like paleosol horizon characterized by higher OC (Molnár and Krolopp 1978) (Fig. 12). According to the results of Quaternary malacological studies implemented on the section (Sümegi 1989), the climate was very similar to the present one at the time, ensuring the sustainment of relatively stable conditions necessary for pedogenesis (Sümegi 1989; Hupuczi and Sümegi 2010). The results of micromorphological investigations seem to corroborate this assumption of a stable warmer climate (increase in bioturbation marks, ferruginous accumulations in the matrix along the pores and cavities). There is a general increase in iron precipitates as well as that of organic remains (charred pine) (K. Náfrádi, pers. comm.). These features are not characteristic of the typical loess horizons. The structure is blocky. However this blocky structure is restricted to the lower parts of the referred horizon. The upper part is unstructured and much more compact. This indicates the cessation of the pedogenesis in the upper parts of the inferred paleosol horizon under a cooling climate characterized by a retreat of the vegetation and the advent of a typical loess mollusk fauna (Sümegi 1989). These conditions prevailed until the end of the Weichselian 3, when the retreat of the typical loess mollusk fauna (including the taxon Trichia hispida) (Sümegi 1989) was accompanied by an advent of ecotone taxa like that of Punctum pygmaeum (Sümegi 1989; Hupuczi and Sümegi 2010). In these horizons a general increase of such micromorphological features can be seen (iron precipitates, shape of pores, frequency of bioturbation marks), which again reflect some degree of pedogenesis. Observations made so far on the paleosol horizons of the Madaras section (Sümegi 1995, 2005; Sümegi et al. 1996) seem to corroborate previous assumptions regarding the micro- and meso-scale complexity of the paleoenvironment of the Carpathian Basin during the last ice age.

\section{Acknowledgements}

The author is grateful to the following persons for their assistance in the preparation of the manuscript: Sándor Gulyás, Attila Bencsik.

This work was supported by grant TÁMOP-4.2.2/B-10/1-2010-0012

Fig. $12 \rightarrow$

Summary of results of previous studies and those of this study for the Madaras section 
356 D. G. Páll et al.

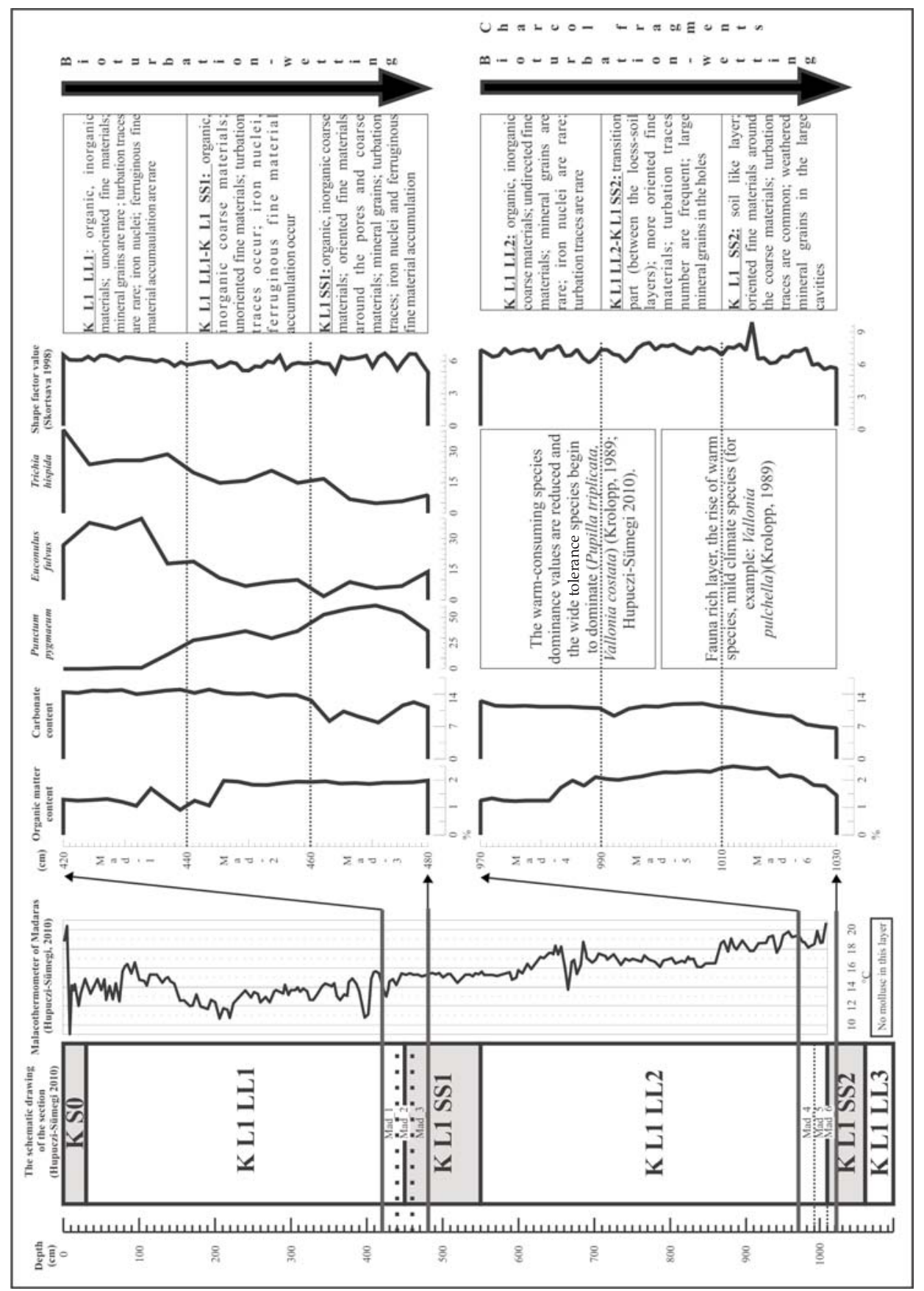

Central European Geology 56, 2013 


\section{References}

Bullock, P., N. Fedoroff, A. Jongerius, T. Tursina, G. Stoops 1985: Handbook for soil thin section description. - Waine Research Publications, England, pp. 152.

Dean, W.E. 1974: Determination of the carbonate and organic matter in calcareous sediments and sedimentary rocks by loss on ignitions: comparison with order methods. - J. Sedimentary Petrology, 44, pp. 242-248.

Dezső, J. 2011: A dél-dunántúli karsztos területek morfológiai, üledékföldtani vizsgálata és összehasonlító értékelésük analóg képződményekkel (Morphological and sedimentological analysis of the South Transdanubian karst areas comparative evaluation of analogous formations). PhD értekezés, 183 p. (In Hungarian.)

FitzPatrick, E.A. 1993: Soil microscopy and micromorphology. - John Wiley and Sons. Chichester. pp. 304.

Hupuczi, J., P. Sümegi 2010: The Late Pleistocene paleoenvironment and paleoclimate of the Madaras section (South Hungary), based on preliminary records from mollusks. - Central European Journal of Geosciences, 2, pp. 64-70.

Jakab, G., P. Sümegi, E. Magyari 2004: A new quantitative method for the paleobotanical description of late Quaternary organic sediments. - Antaeus, 27, pp. 181-211.

Krolopp, E. 1989: A madarasi téglagyári löszfeltárás malakológiai vizsgálata (Analysis of malacological of Brick factory loess section of Madaras). - Cumania, 11, pp. 13-27.

Marosi, S., S. Somogyi 1990: Magyarország kistájainak katasztere I-II (Microregions of Hungary I-II). - Magyar Tudományos Akadémia Földrajztudományi Kutató Intézet, Budapest.

Molnár, B., E. Krolopp 1978: Latest Pleistocene geohistory of the Bácska loess area. - Acta Mineralogica-Petrographica, 23/2, pp. 245-265.

Nebojszki, L. 2005: A Telecskai-dombok lábánál (Hills of Telecska foots). - Természet Világa, 136, pp. 405-408.

Rónai, A. 1977: Negyedidôszaki kéregmozgások a Magyar-medencében (Quaternary tectonical movements in the Hungarian Basin). - Földtani Közlöny, 107, pp. 431-436.

Sümegi, P. 2003: Régészeti geológia és történeti ökológia alapjai (Basics of Archaeological and historical geology, ecology). - JATEPress, $224 \mathrm{p}$.

Sümegi, P., E. Krolopp 1995: A magyarországi würm korú löszök képződésének paleoökológiai rekonstrukciója Mollusca-fauna alapján (Reconstruction of palaeoecological conditions during the deposition of würm loess formations of Hungary based on molluscs). - Földtani Közlöny, 125, pp. 125-148.

Skvortsava, Y. 1998: Micromorphometric types of pore space arrangement in loamy soils of Russian plain. - In ISSS Congress., II. 30. Symp. pp. 565.

Sümegi, P. 1989: Hajdúság felsô-pleisztocén fejlődéstörténete finomrétegtani (üledékföldtani, őslénytani, geokémiai) vizsgálatok alapján (Hajdúság evolution - late pleistocene - of the fine stratigraphic [sedimentological, paleontological, geochemical basis] tests). - Egyetemi doktori értekezés, 96 p. (In Hungarian.)

Sümegi, P. 1995: Az utolsó 30.000 év változásainak rekonstrukciója őslénytani adatok alapján a Kárpát-medence centrális részén (Based on the reconstruction of changes in the last 30,000 years of paleontological data Central part of the Carpathian Basin). - "Berényi Dénes professzor születésének 95 . évfordulója" tiszteletére rendezett tudományos emlékülés előadásai ("Professor Denes Berenyi the 95th anniversary of the birth of" memorial meeting in honor of the scientific presentations). MTA Debreceni Területi Bizottsága, Meteorológiai Munkabizottság és KLTE Meteorológiai Tanszék Kiadvány, pp. 244-258.

Sümegi, P., E. Rudner, E. Hertelendi, S. Borsos, T. Deli, J. Kozák, Gy. Szöőr 1996: Paleoecological research of the loess on the Kopasz mount (Tokaj, North Hungary). - Abstract of "Geomorphology and the Changing Environment in Europe Congress", pp. 112

Sümegi, P. 2005: Loess and Upper Paleolithic environment in Hungary. - Aurea Kiadó, pp. 312. 
Stieber, J. 1967: A magyarországi felsô-pleisztocén vegetációtörténete az anthrakotómiai eredmények (1957-ig) tükrében (The Upper Pleistocene vegetation history of Hungary anthracotomy in the light of results [1957]). - Földtani Közlöny, 97, pp. 308-316.

Szendrei, G. 2000: Talaj-mikromorfológia (Soil-micromorphology). - ELTE-Eötvös Kiadó, 220 p. (In Hungarian).

T. Dobosi, V. 1967: Új felsőpaleolit telep az Alföldön (New upper-paleolit settlers in the Great Plains). - Archeológiai Értesítő, 94, 2, pp. 184-193.

T. Dobosi, V., M. Kőhegyi, M. 1989: Felsőpaleolit telep Madaras-Téglavetőben, ásatások 1966-1974 (Upperpaleolit site in brickyard of Madaras, excavations from 1966 to 1974). - Cumania, 11, pp. 9-11. 